\title{
Impact of Fluorescent In Situ Hybridization Aberrations and CLLU1 Expression on the Prognosis of Chronic Lymphocytic Leukemia: Presentation of 156 Patients from Turkey
}

\author{
Kronik Lenfositik Lösemi Hastalarının Prognozunda Floresan In Situ Hibridizasyon \\ Aberasyonları ve CLLU1 Ekspresyonunun Etkisi: Türkiye'den 156 Hastanın Sunumu
}

\begin{abstract}
(D) Ümmet Abur ${ }^{1}$, (D) Gönül Oğur ${ }^{1}$, (D) Ömer Salih Akar ${ }^{1}$, (D) Engin Altundağ ${ }^{1}$, (D Huri Sema Aymelek ${ }^{1}$, (D) Düzgün Özatlı², (D Mehmet Turgut ${ }^{2}$ ${ }^{1}$ Ondokuz Mayıs University Faculty of Medicine, Department of Medical Genetics, Samsun, Turkey ${ }^{2}$ Ondokuz Mayıs University Faculty of Medicine, Department of Hematology, Samsun, Turkey
\end{abstract}

\section{Abstract}

Objective: This study evaluates the impact of CLLU1 expression and fluorescent in situ hybridization (FISH) analysis of a group of Turkish chronic lymphocytic leukemia (CLL) patients.

Materials and Methods: A total of $156 \mathrm{CLL}$ patients were analyzed by FISH method; 47 of them were also evaluated for CLLU1 expression. Results were correlated with clinical parameters.

Results: FISH aberrations were found in $62 \%$ of patients. These aberrations were del13q14 (67\%), trisomy 12 (27\%), del11q22 (19\%), del $17 p(8 \%)$, and $14 q 32$ rearrangements (20\%). Overall del11q22 and del17p were associated with the highest mortality rates, shortest overall survival (OS), and highest need for medication. Homozygous del13q14, 14q32 rearrangements, and higher CLLU1 expression correlated with shorter OS.

Conclusion: Cytogenetics/FISH analysis is still indicated for routine evaluation of CLL. Special consideration is needed for the poor prognostic implications of del11q22, del17p, 14q32 rearrangements, and homozygous del13q14. The impact of CLLU1 expression is not yet clear and it requires more data before becoming routine in genetic testing in CLL patients.

Keywords: Chronic leukemia, Chronic lymphocytic leukemia, Cytogenetics/FISH, CLLU1

\section{III}

Öz

Amaç: Bu çalışma, bir grup Türk kronik lenfositik lösemi (KLL) hastasında CLLU1 ekspresyonu ve floresan in situ hibridizasyon (FISH) analizinin prognostik etkisini değerlendirmektedir.

Gereç ve Yöntemler: Yüz elli altı KLL hastası FISH yöntemiyle analiz edildi. Bu 156 hastanın 47'sinde ek olarak CLLU1 ekspresyonu incelendi. Sonuçlar klinik parametrelerle ilişkilendirildi.

Bulgular: FISH aberasyonu, hastaların \%62'sinde bulundu. Aberasyonların dağılımı del13q14 (\%67), trizomi 12 (\%27), del11q22 (\%19), del17p (\%8) ve 14q32'nin yeniden düzenlenmesi (\%20) olarak bulundu. En yüksek mortalite, en kısa sağkalım süresi ve en fazla ilaç kullanımı del11q22 ve del17p grubunda idi. Homozigot $13 q 14$ delesyonu, $14 q 32$ yeniden düzenlenmesi ve yüksek CLLU1 ekspresyonu olan hastalar kısa sağkalıma sahipti.

Sonuç: Sitogenetik/FISH analizi, KLL'nin prognostik değerlendirmesinde ve yeni genetik moleküler belirteçlerin belirlenmesinde halen etkili yöntemlerdir. del11q22, del17p, $14 q 32$ yeniden düzenlenmesi ve homozigot del13q14'ün kötü prognostik etkisi gözden kaçırılmamalıdır. CLLU1'in KLL'de prognostik yeri tartışmalıdır. Çalışmamızda orta-kötü prognostik bir kriter olarak belirmesine rağmen, KLL'de rutin genetik testler arasına girebilmesi için daha fazla veri gereklidir.

Anahtar Sözcükler: Kronik lösemi, Kronik lenfositik lösemi, Sitogenetik/FISH, CLLU1 


\section{Introduction}

The clinical manifestation of chronic lymphocytic leukemia (CLL) is variable. While some patients are asymptomatic for years, others show a rapid progression of the disease [1]. Recent identifiers of high-risk patients include chromosomal abnormalities, immunoglobulin heavy chain variable gene, ZAP70, CD38, $\beta 2$ microglobulin and lactate dehydrogenase (LDH), and CLL upregulated gene 1 (CLLU1) expression [2]. The chromosomal abnormality rate in CLL is $30 \%-50 \%$; this rate reaches up to $70 \%-80 \%$ with the fluorescent in situ hybridization (FISH) method $[3,4]$. FISH results have shown that del13q14 is correlated with good prognosis whereas del11q22 and del17p indicate poor prognosis $[5,6]$.

Unfortunately, CLL is genetically heterogeneous. Recently relevant new genomic abnormalities such as NOTCH1 and SF3B 1 mutations as well as BIRC3 disruptions have been described $[7,8]$, but none of these genetic markers are unique to CLL. CLLU1 is defined as the first gene specific to CLL. The high expression level of CLLU1 seems to be unique in CLL [9]. However, its relevance to prognosis is still unclear.

In this study, the distribution and prognostic impact of chromosomal aberrations via FISH as well as CLLU1 expression levels were analyzed in a group of North Anatolian CLL patients.

\section{Materials and Methods}

\section{Patients}

Interphase FISH analysis was applied to blood or bone marrow samples of $156 \mathrm{CLL}$ patients. Of these, 47 were also evaluated for CLLU1 expression and compared with 35 healthy controls. Staging was done according to the modified Rai staging (MRS) system. The results of the $\beta 2$ microglobulin, LDH, white blood cell (WBC) count, and absolute lymphocyte count were grouped as high or low risk (Table 1)

FISH data were categorized as group 1: del13q14, group 2: trisomy 12, group 3: del11q and del17p, and group 4: normal FISH results. Additionally, two groups were formed with $14 q 32(\mathrm{IGH})$ rearrangements being positive or normal.

\section{Interphase FISH}

FISH analysis was performed by directly labeled probes (Vysis) Abbott Co., Abbott Park, IL, USA). A FISH panel of 5 probes (D13S319, LSI 13q34, LSI ATM, CEP12, LSI p53) was applied [10]. Seventy-one out of 156 patients were also tested by $14 q 32$ break-apart probe.

FISH analyses were conducted using an Olympus BX51 microscope equipped with a Progressive Scan Video Camera (Tokyo, Japan). Image analysis was carried out with CytoVision software (version 3.93; Applied Imaging, Grand Rapids, MI, USA). For each probe for optimization, a cut-off level was obtained by counting 300 cells. Results were considered clonal when the percentage of cells with any given chromosome abnormality exceeded the normal cut-off value.

\section{CLLU1 Expression}

For the analysis of CLLU1 expression, RNA was isolated (OIAGEN, Hilden, Germany); cDNA was synthesized using a cDNA Reverse Transcription Kit (Ipsogen, QIAGEN). CLLU1 expression was tested by real time-polymerase chain reaction (Rotor-Gene 0, QIAGEN) using primers/probes previously defined (Ipsogen, CLLU1 Profile Quant Kit). Analysis was performed using the comparative $\mathrm{Ct}$ method of relative quantification with $\beta 2$ microglobulin as an endogenous control. The CLLU1 expression levels were measured as fold upregulation in relation to normal patients' cells and a

Table 1. Distribution of patients according to risk groups and chromosomal abnormalities (fluorescent in situ hybridization).

\begin{tabular}{|c|c|c|c|c|c|c|c|c|}
\hline & \multicolumn{2}{|c|}{$\begin{array}{l}\text { White blood cell } \\
\text { count }\end{array}$} & \multicolumn{2}{|c|}{ Absolute lymphocyte count } & \multicolumn{2}{|c|}{$\beta 2$ Microglobulin } & \multicolumn{2}{|c|}{ Lactate dehydrogenase } \\
\hline $\begin{array}{l}\text { FISH } \\
\text { anomalies }\end{array}$ & $\begin{array}{l}\text { Low } \\
\text { risk } \\
\left(<50 \times 10^{3} / \mu \mathrm{L}\right)\end{array}$ & $\begin{array}{l}\text { High } \\
\text { risk } \\
\left(\geq 50 \times 10^{3} / \mu \mathrm{L}\right)\end{array}$ & $\begin{array}{l}\text { Low } \\
\text { risk } \\
\left(<30 \times 10^{3} / \mathrm{uL}\right)\end{array}$ & $\begin{array}{l}\text { High } \\
\text { risk } \\
\left(\geq 30 \times 10^{3} / \mu \mathrm{L}\right)\end{array}$ & $\begin{array}{l}\text { Low } \\
\text { risk } \\
(<2300 \mathrm{~g} / \\
\mathrm{mL})\end{array}$ & $\begin{array}{l}\text { High } \\
\text { risk } \\
\text { ( } \geq 2300 \\
n g / m L)\end{array}$ & $\begin{array}{l}\text { Low } \\
\text { risk } \\
\text { (<500 } \\
\text { U/L) }\end{array}$ & $\begin{array}{l}\text { High } \\
\text { risk } \\
\text { ( } \geq 500 \mathrm{U} / \mathrm{L})\end{array}$ \\
\hline $\begin{array}{l}\text { del } 11 q 22 / \text { del17p } \\
\text { (TP53) }\end{array}$ & $12(50 \%)$ & $12(50 \%)$ & 7 & $17(71 \%)$ & 6 & $17(71 \%)$ & 7 (78\%) & $2(22 \%)$ \\
\hline del13q14 & $24(65 \%)$ & $13(35 \%)$ & 20 & $17(45 \%)$ & 19 & $15(44 \%)$ & $36(95 \%)$ & $2(5 \%)$ \\
\hline Trisomy 12 & $14(65 \%)$ & $5(35 \%)$ & 15 & $4(21 \%)$ & 8 & $10(55 \%)$ & $14(74 \%)$ & $5(26 \%)$ \\
\hline Normal & 47 (79\%) & $13(21 \%)$ & 42 & $18(30 \%)$ & 22 & $32(60 \%)$ & 51 (88\%) & $7(12 \%)$ \\
\hline$p$-value & \multicolumn{2}{|l|}{$<0.05$} & \multicolumn{2}{|l|}{$<0.05$} & \multicolumn{2}{|l|}{$>0.05$} & \multicolumn{2}{|l|}{$>0.05$} \\
\hline
\end{tabular}


cut-off value was defined to separate high from low expression levels [11].

\section{Statistical Analysis}

The chi-square test was applied to determine the relationship among clinical and laboratory parameters (LDH and $\beta 2$ microglobulin, WBC, MRS, CLLU1 expression, and subsets of FISH abnormalities). Overall survival (OS) was tested by the KaplanMeier method. The survival curves were statistically compared using a log-rank test $(p \leq 0.05)$.

\section{Results}

\section{Patient Population}

Of 156 patients, 103 patients were male. Ages ranged from 36 to 90 years (median: 68 years). In total, 37 patients died during the study. The median OS time was $101 \pm 12$ months.

\section{Results of FISH}

FISH analysis detected aberrations in 96 patients (62\%). The most frequent abnormality was del13q14 (67\%), followed by trisomy 12 (27\%), del11q22 (19\%), and del17p13 (8\%). The occurrence of del13q14 and del11q22 was the most frequent complex abnormality (Table 2). 14q32 rearrangements were detected in 14 of 71 patients (20\%).

The shortest survival was observed with del11q and del17p and trisomy 12; the longest survival was with del13q14 and in normal patients $(p>0.05)$. The need for medication was significantly higher for del11q22 and del17p $(p<0.05)$. Homozygous del13q14 showed twofold shorter OS ( $p>0.05)$ and was categorized in the high-risk group $(p<0.05)$ (Table 3$)$. Positive $14 q 32$ rearrangements showed a twofold increase in mortality and need for medication ( $p>0.05$ ). They were categorized in the intermediate- to high-risk group $(p<0.05)$.
FISH results were correlated with MRS. The $11 q 22$ and $17 p 13$ deletions had an advanced stage $(p<0.05)$, as well as higher WBC and absolute lymphocyte counts $(p<0.05)$. No difference was observed within groups with respect to $\beta 2$ microglobulin and LDH and initiation of therapy ( $p>0.05)$ (Table 1).

\section{Results of CLLU1 Expression}

CLLU1 expression represented a continuum ranging from 0.1 to 3900 and a median of 17.6-fold upregulation (Figure 1). In the group with high CLLU1 expression, survival time was twofold lower and the need for medication was twofold higher $(p>0.05)$. High CLLU1 expression was associated with higher WBC count.

Table 2. Frequencies of fluorescent in situ hybridization anomalies in chronic lymphocytic leukemia patients.

\begin{tabular}{|l|l|l|}
\hline Main FISH anomalies & Patient (n) & Percent (\%) \\
\hline Heterozygote del13q14 & 64 & 67 \\
\hline Trisomy 12 & 26 & 27 \\
\hline del11q22 & 18 & 19 \\
\hline del17p13 & 8 & 8 \\
\hline Complex FISH anomalies & \multicolumn{2}{|l|}{} \\
\hline del13q14 + del11q22 (most common) & 9 & 33 \\
\hline Homozygote del13q14 & 6 & 22 \\
\hline del11q22 + trisomy 12 & 2 & 7 \\
\hline del13q14 + del17p13 & 3 & 11 \\
\hline del13q14 + trisomy 12 & 4 & 15 \\
\hline del13q14 + del13q34 & 1 & 4 \\
\hline del13q14 + del13q34 + del17p13 & 1 & 4 \\
\hline Homozygote del13q14 + del17p13 & 1 & 4 \\
\hline Total & 27 & 100 \\
\hline FlSH: Fluorescent in situ hybridization. & & \\
\hline
\end{tabular}

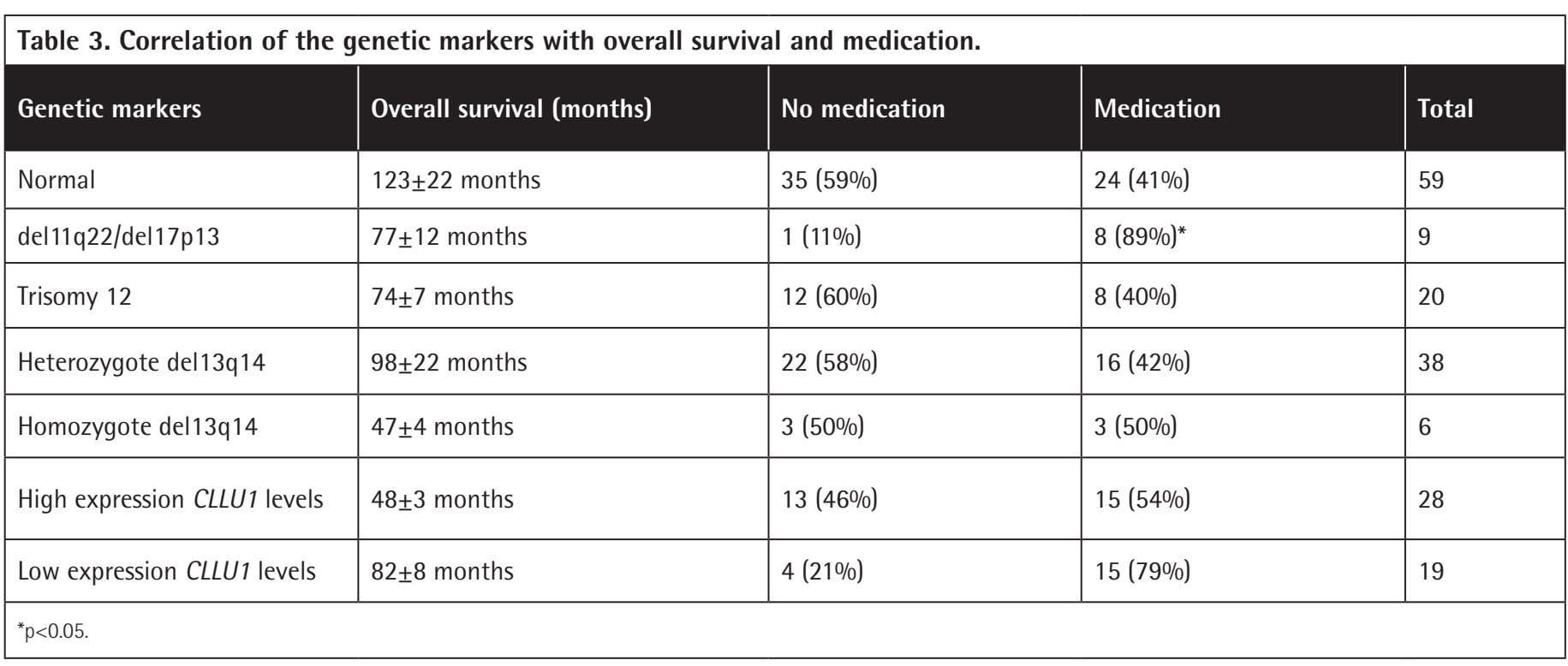




\begin{tabular}{|c|c|c|c|c|c|c|}
\hline & Overall survival & $\begin{array}{l}\text { Need for } \\
\text { medication }\end{array}$ & Advanced stage & $\begin{array}{l}\text { High } \beta 2 \\
\text { microglobulin level }\end{array}$ & $\begin{array}{l}\text { FISH } \\
\text { anomalies }\end{array}$ & Age \\
\hline Our study & $\begin{array}{l}\text { Shorter } \\
(p>0.05)\end{array}$ & $\begin{array}{l}\text { High } \\
(p>0.05)\end{array}$ & $\overline{(p>0.05)}$ & $\overline{(p>0.05)}$ & $\begin{array}{c}- \\
(p>0.05)\end{array}$ & $\overline{(p>0.05)}$ \\
\hline Buhl et al. [18] & $\begin{array}{l}\text { Shorter } \\
(p<0.05)\end{array}$ & $\begin{array}{l}\text { High } \\
(p<0.05)\end{array}$ & $\stackrel{+}{(p<0.05)}$ & NA & $\begin{array}{l}+^{*} \\
(p<0.05)\end{array}$ & NA \\
\hline Chen et al. [20] & NA & NA & $\begin{array}{l}+ \\
(p<0.05)\end{array}$ & NA & $\overline{(p>0.05)}$ & NA \\
\hline $\begin{array}{l}\text { Josefsson et al. } \\
\text { [11] }\end{array}$ & $\begin{array}{l}\text { Shorter } \\
(p<0.05)\end{array}$ & $\begin{array}{l}\text { High } \\
(p<0.05)\end{array}$ & $\overline{(p>0.05)}$ & NA & $\begin{array}{l}+^{*} \\
(p<0.05)\end{array}$ & $\overline{(p>0.05)}$ \\
\hline $\begin{array}{l}\text { Gonzalez et al. } \\
\text { [19] }\end{array}$ & $\begin{array}{l}\text { Shorter } \\
(p<0.05)\end{array}$ & $(p>0.05)$ & NA & $\begin{array}{l}+ \\
(p<0.05)\end{array}$ & $\overline{(p>0.05)}$ & $\begin{array}{l}+ \\
(\mathrm{p}<0.05)\end{array}$ \\
\hline
\end{tabular}

There was no correlation between CLLU1 expression and FISH anomalies, $\beta 2$ microglobulin and LDH levels, or MRS ( $p>0.05$ ).

\section{Discussion}

Genetic markers have been major factors in the prognostic evaluation of CLL. The chromosomal anomaly detection rate with FISH is $70 \%-80 \%$ [3]. In our study, the FISH abnormality rate was $62 \%$. Detected abnormalities include del13q14 (40\%-60\%), trisomy 12 (15\%-20\%), del11q22 (10\%-20\%), and del17p13 (5\%-10\%). Our study yielded a similar pattern. Survival was significantly shorter among patients with del11q12 and del17p13. Similar to the literature data, significant correlation was observed between these two deletions and poor prognosis $[5,6,12]$. In this study, patients with positive $14 q 32$ rearrangements also had poor outcomes, as shown in some previous reports $[13,14]$.

Few studies refer to homozygote del13q14, and its contribution to prognosis is unclear. Some have reported that homozygote del13q14 is associated with an advanced stage $[15,16]$, while Puiggros et al. [17] noted the opposite. In our study, homozygote del13q14 was correlated with advanced stage and shorter survival.

Previous studies reported that TP53, NOTCH, SF3B1, and BIRC3 mutations are accountable for poor prognosis $[7,8]$. The impact of CLLU1 expression as a new prognostic factor in CLL is unclear. In the present report, high CLLU1 expression indicated shorter survival and higher need for treatment. Similar results were observed in the literature $[11,18,19]$.

In our study, there was no correlation between CLLU1 expression and FISH aberrations. Some have reported that patients with del17p13 and del11q22 have significantly higher levels of CLLU1 $[11,18]$. Chen et al. [20] noted the opposite. Buhl et al. [21] reported no increase in the level of CLLU1 in patients with trisomy 12; Gonzalez et al. [19] noted the opposite. There was no correlation between trisomy 12 and CLLU1 expression in our study (Table 4).

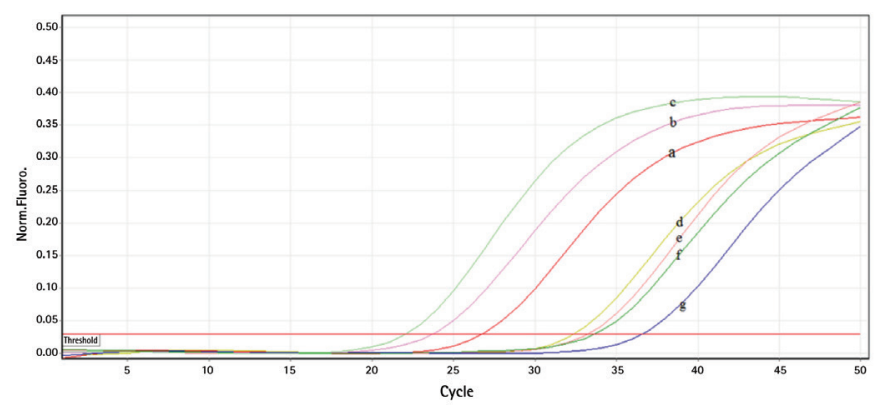

Figure 1. Levels of CLLU1 expression: $a, b, d, g$ - patients; cstandard; e, f- healthy controls.

\section{Conclusion}

A chromosomal evaluation is still needed for the genetic evaluation of CLL because it can identify unique translocations or aberrations in which breakpoints could lead to identification of new molecular markers. Application of a FISH panel including probes aiming to detect homozygous del13q14, del11q22, del17p, 14q32 rearrangements, and trisomy 12 should still be the routine. The impact of testing CLLU1 expression is not yet clear and there is a need for more relevant data.

\section{Ethics}

Ethics Committee Approval: This study had the permission of the Ondokuz Mayıs University Ethical Committee (approval number: 201/855).

Informed Consent: It was received.

\section{Authorship Contributions}

Surgical and Medical Practices: G.O., M.T., D.Ö.; Concept: G.O., D.Ö., M.T.; Design: Ü.A., Ö.S.A., H.S.A.; Data Collection or Processing: Ü.A., E.A., Ö.S.A.; Analysis or Interpretation: Ü.A., E.A.; Literature Search: Ü.A., H.S.A., E.A., Ö.S.A.; Writing: G.O., Ü.A. 
Conflict of Interest: The authors of this paper have no conflicts of interest, including specific financial interests, relationships, and/or affiliations relevant to the subject matter or materials included.

\section{References}

1. Gentile M, Mauro FR, Guarini A, Foà R. New developments in the diagnosis, prognosis and treatment of chronic lymphocytic leukemia. Curr Opin Oncol 2005; 17:597-604.

2. Byrd JC, Stilgenbauer S, Flinn IW. Chronic lymphocytic leukemia. Hematology Am Soc Hematol Educ Program 2004;163-183.

3. Dicker F, Schnittger S, Haferlach T, Kern W, Schoch C. Immunostimulatory oligonucleotide-induced metaphase cytogenetics detect chromosomal aberrations in $80 \%$ of CLL patients: a study of $132 \mathrm{CLL}$ cases with correlation to FISH, IgVH status, and CD38 expression. Blood 2006;108:3152-3160.

4. Shanafelt TD, Geyer SM, Kay NE. Prognosis at diagnosis: integrating molecular biologic insights into clinical practice for patients with CLL. Blood 2004;103:1202-1210.

5. Lai YY, Huang XJ. Cytogenetic characteristics of B cell chronic lymphocytic leukemia in 275 Chinese patients by fluorescence in situ hybridization: a multicenter study. Chin Med J (Engl) 2011;124:2417-2422.

6. Döhner $H$, Stilgenbauer $S$, Benner $A$, Leupolt $E$, Kröber $A$, Bullinger $L$, Döhner K, Bentz M, Lichter P. Genomic aberrations and survival in chronic lymphocytic leukemia. N Engl J Med 2000;343:1910-1916.

7. Puiggros A, Blanco $G$, Espinet B. Genetic abnormalities in chronic lymphocytic leukemia: where we are and where we go. Biomed Res Int 2014;2014:435983.

8. Stilgenbauer S, Schnaiter A, Paschka P, Zenz T, Rossi M, Döhner K, Bühler A, Böttcher $S$, Ritgen $M$, Kneba M, Winkler D, Tausch E, Hoth P, Edelmann J, Mertens D, Bullinger L, Bergmann M, Kless S, Mack S, Jäger U, Patten N, Wu $L$, Wenger MK, Fingerle-Rowson G, Lichter P, Cazzola M, Wendtner CM, Fink AM, Fischer K, Busch R, Hallek M, Döhner H. Gene mutations and treatment outcome in chronic lymphocytic leukemia: results from the CLL8 trial. Blood 2014:123:3247-3254.

9. Buhl AM, James DF, Neuberg D, Jain S, Rassenti LZ, Kipps TJ. Analysis of CLLU1 expression levels before and after therapy in patients with chronic lymphocytic leukemia. Eur J Haematol 2011;86:405-411.

10. Schoch $C$, Schnittger $S$, Bursch $S$, Gerstner D, Hochhaus A, Berger U, Hehlmann R, Hiddemann W, Haferlach T. Comparison of chromosome banding analysis, interphase and hypermetaphase-FISH, qualitative and quantitative PCR for diagnosis and for follow-up in chronic myeloid leukemia: a study on 350 cases. Leukemia 2002;16:53-59.

11. Josefsson P, Geisler CH, Leffers $\mathrm{H}$, Petersen JH, Andersen MK, Jurlander J, Buhl AM. CLLU1 expression analysis adds prognostic information to risk prediction in chronic lymphocytic leukemia. Blood 2007;109:4973-4979.
12. Ripollés $L$, Ortega $M$, Ortuño $F$, González $A$, Losada J, Ojanguren J, Soler JA, Bergua J, Coll MD, Caballin MR. Genetic abnormalities and clinical outcome in chronic lymphocytic leukemia. Cancer Genet Cytogenet 2006;171:57-64.

13. Pittman S, Catovsky D. Prognostic significance of chromosome abnormalities in chronic lymphocytic leukaemia. Br J Haematol 1984;58:649-660.

14. Cavazzini F, Hernandez JA, Gozzetti A, Russo Rossi A, De Angeli C, Tiseo R, Bardi A, Tammiso E, Crupi R, Lenoci MP, Forconi F, Lauria F, Marasca R, Maffei R, Torelli G, Gonzalez M, Martin-Jimenez P, Maria Hernandez J, Rigolin GM, Cuneo A. Chromosome $14 q 32$ translocations involving the immunoglobulin heavy chain locus in chronic lymphocytic leukaemia identify a disease subset with poor prognosis. Br J Haematol 2008;142:529-537.

15. Stilgenbauer $S$, Sander $S$, Bullinger L, Benner A, Leupolt E, Winkler D, Kröber $A$, Kienle D, Lichter $\mathrm{P}$, Döhner $\mathrm{H}$. Clonal evolution in chronic lymphocytic leukemia: acquisition of high-risk genomic aberrations associated with unmutated $\mathrm{VH}$, resistance to therapy, and short survival. Haematologica 2007;92:1242-1245.

16. Shanafelt TD, Witzig TE, Fink SR, Jenkins RB, Paternoster SF, Smoley SA, Stockero KJ, Nast DM, Flynn HC, Tschumper RC, Geyer S, Zent CS, Call TG, Jelinek DF, Kay NE, Dewald GW. Prospective evaluation of clonal evolution during long-term follow-up of patients with untreated early-stage chronic lymphocytic leukemia. J Clin Oncol 2006;24:4634-4641.

17. Puiggros $A$, Delgado J, Rodriguez-Vicente $A$, Collado $R$, Aventín $A$, Luño E, Grau J, Hernandez JÁ, Marugán I, Ardanaz M, González T, Valiente A, Osma M, Calasanz MJ, Sanzo C, Carrió A, Ortega M, Santacruz R, Abrisqueta $P$, Abella $E$, Bosch $F$, Carbonell F, Solé $F$, Hernández JM, Espinet B; Grupo Cooperativo Español de Citogenética Hematológica (GCECGH) and Grupo Español de Leucemia Linfática Crónica (GELLC). Biallelic losses of 13q do not confer a poorer outcome in chronic lymphocytic leukaemia: analysis of 627 patients with isolated 13q deletion. Br J Haematol 2013;163:47-54.

18. Buhl AM, Jurlander J, Geisler CH, Pedersen LB, Andersen MK, Josefsson P, Petersen JH, Leffers H. CLLU1 expression levels predict time to initiation of therapy and overall survival in chronic lymphocytic leukemia. Eur J Haematol 2006;76:455-464.

19. Gonzalez D, Else M, Wren D, Usai M, Buhl AM, Parker A, Oscier D, Morgan G, Catovsky D. CLLU1 expression has prognostic value in chronic lymphocytic leukemia after first-line therapy in younger patients and in those with mutated IGHV genes. Haematologica 2013;98:274-278.

20. Chen L, Li J, Zheng W, Zhang Y, Wu Y, Li L, Qian S, Xu W. The prognostic evaluation of CLLU1 expression levels in 50 Chinese patients with chronic lymphocytic leukemia. Leuk Lymphoma 2007;48:1785-1792.

21. Buhl AM, Jurlander J, Jørgensen FS, Ottesen AM, Cowland JB, Gjerdrum $L M$, Hansen BV, Leffers $H$. Identification of a gene on chromosome 12 22 uniquely overexpressed in chronic lymphocytic leukemia. Blood 2006;107:2904-2911. 